\title{
How does the akratês intentionally do what he intended not to without changing his mind? ${ }^{1}$
}

Terms related to the concept of akrasia are paradigmatically used when one does something that one knows does not coincide with one's conception of doing well. Such doing may be explained as being 'due to weakness'. Alternatively, one may recognize that one was quite clear-headed in acting akratically; at the time of committing such an action, one may have reasoned that, for once, one did not care. Now such occurrences, in the life of an agent, are hardly controversial. The problem is that it becomes surprisingly difficult to conceptualize the case where one clearheadedly intends to act contrary to one's convictions about what it is good to do in such-and-such circumstances; cases which are surely exceedingly and disappointingly common. Indeed, Anscombe complains that, whereas Aristotle deals with cases where passion, or failure to keep clear one's proper ends before one's mind explains akrasia, “[h]e apparently cannot admit the case where a person forms a perfectly clear-headed intention of acting contrary to his convictions". 2

One difficulty, here, appears to be the propensity of certain philosophers to assimilate practical reasoning to theoretical reasoning to the greatest possible extent. The blame for this mischief may, indeed, partly be laid at Aristotle's door. For, in his explanation of practical reasoning - an extremely important conceptual innovation of his - he often tries hard to show it to be, formally, as similar as possible to theoretical reasoning ${ }^{3}$. He shows himself to be keen on this assimilation particularly in De motu animalium; his reason is that he wants to make the manner, in which the practical syllogism sets the (human) animal in motion, clear. ${ }^{4}$ However, one must aver that, while there certainly are law-like generalizations about human actions, these are not mechanical generalizations.

One must here attend to the categorial distinction -between reasons and causes. To use the example Anscombe refers to in the last paragraph of her landmark work Intention, ${ }^{5}$ if one were to ask St Peter why he was feeling afraid in the courtyard, he could have replied that he was afraid of

\footnotetext{
Submitted by Rev. Dr Mark Sultana, Lecturer in Philosophical Theology at the University of Malta.

G.E.M. Anscombe, Thought and Action in Aristotle, in The Collected Philosophical Papers of G.E.M. Anscombe Vol I: From Parmenides to Wittgenstein, Basil Blackwell, Oxford 1981, 72.

3 See David Wiggins, "Weakness of Will, Commensurability and the Objects of Deliberation and Desire," in Essays on Aristotle's Ethics, ed. Amélie Oksenberg Rorty (Berkeley/CA: University of California Press, 1980), 248. One needs to note that Aristotle also stresses that practical reasoning is concerned with 'things that might actually be otherwise', its premisses not being apodeictic (see Aristotle, Nicomachean Ethics, VI, 1140a 33-35).

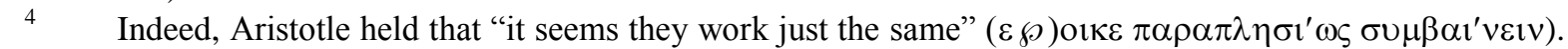
Aristotle, De motu animalium, VII, 701a 8.

5 G.E.M. Anscombe, Intention, Harvard University Press 2000, $\$ 52$.
} 
ending up in the same way as Jesus did. ${ }^{6}$ Such an utterance would manifest the reason for his fear which he does not discover; indeed, he could not have been completely unaware of it. Of course, one might then go on to ask him why he was afraid of that and his answer may have assigned a cause to his fear in that particular situation: 'Because of what happened in the garden of Gethsemane'. This, more than his reason for being afraid, was what made him afraid; that is, it was the cause, which he might have to discover, of his fear. ${ }^{7}$ This categorial distinction is central precisely because human action - and akrasia - belongs conceptually with reasons and motives not with causes.

Now, the case Anscombe has highlighted is an especially hard one. For St Peter did what he intended not to intentionally. In addition, as Anscombe noted, Peter's action was not a matter of his changing his mind about betraying Christ in such a way that he could justify doing so for a reason. To be sure, if that were the case, one would not speak of akrasia at all. Indeed, we need to seek an answer to the question: how does the akratês act differently without changing his mind?

It is evident that, in Peter's case, remaining faithful to Jesus was not just a question of a banal promise or intention; it was part of his character, that is, part of his conception of what a human being's doing well in the circumstances would mean. Such a conception certainly enabled him to see what was practically relevant in his circumstances. He followed Jesus' tracks even when they led him to the High Priest's courtyard - not the safest place for Peter at the time. Of course, the danger in the situation was also registered by Peter, and this was liable to and, indeed, probably did, trigger a motivational susceptibility in him, which susceptibility was completely innocent with regards to his character as faithful disciple and friend; initially, at least, he gave it no practical importance. On entering the courtyard, what mattered about the situation was not that it was dangerous but, rather, that Jesus was under arrest and was being questioned there, and that he must not leave him alone.

One must not forget that the conception of doing well in the circumstances is not an abstract framework of self-evident propositions or logical principles. If one is to talk of propositions at all, as belonging to and forming this background, one must speak of empirical 'propositions' with a peculiar logical form. Here one will surely recall that, in his work On Certainty, Ludwig Wittgenstein noted that such 'propositions' simply hold fast for the agent in his or her life. To be

\footnotetext{
${ }^{6}$ The example refers to the betrayal of Jesus by Peter, recounted with great sensitivity to psychological detail, in Lk 22, 31-62.

Of course, it might be the case that a single state of affairs be both the object and the cause of the motive. One might, for instance, feel depressed because of one's failing health where the latter is both the object and the cause of one's feeling. The distinction, however, remains conceptually important.
} 
sure, in different circumstances and with different experiences, individual ways of judging and acting can change their role in the language-game and become more fluid, just as more fluid 'propositions' may become more solid. Also, while they do have a similar role, not all certainties have the same logical role. Their similar role lies in that one does not call them into question. The differences lie precisely in what it would take for one to doubt, or question, or be able to proceed intelligibly outside such judgments and ways of acting. ${ }^{8}$ And different circumstances could make one call into question different such certainties. For example, in Peter's case, what was in question was never his belonging and devotion to his own family, nor was it his recognition of God. Perhaps, a live doubt here would have dragged down everything with it and plunged it into chaos. Sadly, however, the dangerous circumstances did put Peter in a position where he was able to question what, hitherto, had been unquestioned in his life. ${ }^{9}$

Indeed, the dangerous circumstances, and the connected fear constituted an extremely salient persuasive aspect which could have meant that Peter saw other practically relevant features in the situation; the violent animosity against anyone related to Jesus, for instance. Now, such a picture of practically relevant features of the situation would be entirely different from the one connected to his purpose not to betray Jesus; one could say that it partly constituted a different world. Just as Wittgenstein maintained in On Certainty, there is a logical gap between reasons and convictions; reasons, like justifications and explanations necessarily come to an end, and then one is convinced or acts one way or another. If one were to ask Peter the reason why he acted - whether he acted in

8 As such, in different circumstances, one can see that, what constituted an unshakeable conviction or what one really, really wanted becomes a supposition that one could question and which one could see as reasonable, or unreasonable, in the circumstances. Indeed, it is here that one speaks of people with more or less character - according as their ethical convictions remain untouchable in more or less 'extreme' circumstances, and over longer or shorter timeframes. And, it must be said that one might have great character in one area (say, temperance) and less character in another (say, courage).

Such 'adverse' circumstances may be of different kinds in one's life. They may range from suggestions that tempt one to do something out of character, to bodily needs, or different emotional states that may be more or less intense, to moods or bodily dispositions, and so forth. Of course, such circumstances are to be seen, not as causes but as constituting possible persuasive reasons for the agent's actions. That is, the agent can say what he or she is doing without the need for self-observation of any kind and can see the quest for reasons for the acts as intelligible. If such a quest is itself seen as senseless, one must consider that the act was not a human action and, therefore, not akratic.

Given that certain bodily needs and sensations, such as sleepiness, lust and nausea, and even certain emotional states like anger - which are not conceptually the same as bodily sensations since, unlike in the case of emotions, it is possible to be hungry, for instance, without being hungry for anything in particular; but which are sufficiently similar in that both have genuine duration, and are linked with characteristic forms of expression - may be more or less intense, the best way to avoid akratic actions might be to avoid circumstances that render them more intense and, therefore, more persuasive, thereby making one's decision not to pursue them outside one's conception of doing well less difficult.

Indeed, particularly in the case of bodily sensations and needs, there might be a point where cause takes over and one cannot help but sleep, for example. Only in such cases can one speak of irresistible impulses or desires: that is, in cases where one is caused to act. Nevertheless, the wider context of the act, normally, remains voluntary and may well be intentional; while the concept of akrasia is not used within the first context, it could be used, if the case indicates this, within this wider context. 
character or not - the answer he would give would hark to the desirability characterization he in fact acted upon. And if one were to press him as to why he chose one and not the other, he could well show that the question is empty and senseless. For the particular desirability characteristic he chose was what he would call a good reason in connection with his actual practice; that was just the way he judged, and just the way he acted.

Peter's basic conviction was clearly his fidelity to Jesus. And this remained central to Peter's conception of excellence in the sense that it constituted the background within which value judgments in his life could be what they were and show what is deplorable and what not in his actions. It was this conception that was logically connected to opprobrium or satisfaction in his life. However, his situation was not a case where the alternative conviction - in this case, that of fear and the value of his safety - could not be understood. Neither was it a case where acting this way - that is, showing fear and thereby betraying Jesus - would destroy the whole business of judging and acting well. Peter's character was not annihilated, even when he knowingly did what he knew to be wrong. Indeed, he never did contradict his intention not to betray Jesus. One would say that Peter's wanting absolutely to remain faithful to Jesus and his wanting, at all costs, to protect his own safety do not conflict but, rather, they pass one another by: they shape and belong to two different practical pictures of the world.

What we have here is a conflict of ultimate reasons or purposes for action that is not a merely empty or abstract one, but a real-life dilemma. The situation ends in (renewed) conviction, decision, or persuasion. However, it is not that Peter discussed with himself the pros and cons of one or the other. What underlay his life and his judgment at the time was a going on without any further reason. Of course, he could have refused to revise his practical judgment no matter how much the facts around him bucked. Again, however, he would not have done so for a further reason. What was there was an ultimate response to the quest for reasons, an intentional cleaving to a purpose, by Peter. The result was something like: this is what I will hold, what I really, really want in the circumstances! And what Peter really, really wanted in acting akratically, the ultimate 'ground' he acted upon, was to look out for himself.

Once again, one must stress that this conviction does not contradict that of not betraying Jesus. At no point does Peter change his mind and want, as his ultimate 'ground', to betray Jesus! It is just that, when he did betray Jesus, that intention which was part of his conception of doing well ceased to be a reason for or against any action: his 'ground' for acting was other. Indeed, Peter's ultimate purpose, from that of wanting to remain faithful to Jesus, became that of saving his skin. It is a situation where Peter suddenly sees a new aspect of the situation; he sees that a new kind of description can be given of the situation which remains the same yet now looks different so that 
what is practically pertinent to him is different. It is as if he has brought a new aspect to what he sees, and he now sees the aspect along with the situation. It is itself hardly visible, and yet it spreads an ordering veil over the entire situation. ${ }^{10}$ Sadly, Peter could also say what he was doing in looking out for his own safety by denying that he knew Jesus, and once he decided for his new purpose in the circumstances, and acted accordingly, he did betray Jesus intentionally.

For it was his decision to pursue the other ultimate purpose of saving his skin. What he did, in answering the servants, was, of course, intentional; what he was also doing was betraying Jesus but this had ceased to count as a 'rule' or a value judgment marked by certainty - its role became that of a description of an aspect which was no longer practically relevant but only factually recognized. His purpose to remain faithful was not contradicted but, rather, it ceased to be used, by Peter, as a 'rule'.

Of course, when Peter went for another conception or 'ground' or ultimate reason for doing well in the circumstances because he wanted to, he knew he was not acting as he should. The opprobrium, at his decision or his allowing himself to be persuaded by an ultimate purpose that lay outside of the possibilities his conception of a good life showed him, was there. Such opprobrium could have been manifested in a number of ways: the deliberate shamelessness needed to say 'So what!', or the attempt to excuse oneself: 'There is nothing else I can do'. The opprobrium overcome, the agent - Peter in this case - now has a different practical picture and what he sees as salient now is connected logically to his new 'ground' or purpose.

It is instructive to note at this point that, before betraying Jesus, Peter could well have made the assertion: 'I will never betray you ... unless I do' without contradiction! After all, Jesus did know that what Peter was averring was not going to be fulfilled and it would be absurd to think that what Jesus was saying was going to happen was not the very same thing as what Peter was saying was not going to happen. To elucidate further how this is so, it is useful to note that Peter could grammatically not have added, immediately and spontaneously '.. but I intend to do so', or '.. but I want to betray you', after avowing that he wanted not to be disloyal. For one cannot at the same time and in the same respect be conforming to a 'rule' and to its contradictory.

Nevertheless, one must admit that had Jesus not spoken, and had the situation not been so dire, the very thought that Peter might not, after all, remain faithful to Jesus would have seemed almost absurd to him. Here one must note two things. The first is that, while sometimes it does happen that people act out of character or contrary to their firm intention, mostly it does not; and when it does happen, it happens mostly in adverse or strange circumstances. The second point is that such

\footnotetext{
10 See Ludwig Wittgenstein, Remarks on the Philosophy of Psychology, I. Translated by G. E. M. Anscombe. Edited by G. E. M. Anscombe and G. H. von Wright. Oxford: Basil Blackwell, 1980, §961.
} 
an action, contrary to one's character or firm intention, would not be a mistake. It would, rather, be something else: it would be seen as folly or absurdity. Peter, in expressing his intention, manifested a logical connection with acts that show fidelity; acts that constituted betrayal must have been viewed by him, not as mistaken but as excluded; not as false - and, therefore, possibly true - but as forbidden. ${ }^{11}$

Therefore, while it is always logically possible to utter a statement like 'I will never betray you ... unless I do', in Peter's case, such an utterance is even more plausible given the context of Jesus' prophecy where, as a third person, he made it possible for Peter to think that. In more general terms, in the wider context that encompasses one's utterances - which, after all, includes other persons -, one can look on oneself and one's utterances, as if one were a third person; after all the 'I' who utters is also a third person in the world.

Now, when Peter was actually committing the akratic deed, he could say for what reason he was doing that. In addition, he could say that he was being akratic, not within the background of his present 'purpose-ground' but, rather, within the background of his remembered intention which showed his character. In this sense, Peter would then be taking up the same relation to his description of his own character as if it 'belonged' to a third party. One must here note that it is not as if he were a completely different person: he would recognize some continuity in his life, even if, at the time, he rejected as irrelevant what he could have seen went unquestioned before, since some yardsticks of judging and acting remained fixed in his life. Indeed, he has not, and cannot have jettisoned all such values, norms, and certainties for others. One must also note that, while he can see that his action is aberrant and foolish in the light of his previous conception, he is not remorseful at the time he commits what he sees to be akratic since that action is intelligible in the context of the practical picture of the world he has intentionally cleaved to. Later, in his remorseful state, Peter could understand why he was so shockingly disloyal; he could understand his action as intelligible both within the background of his erstwhile world-picture, and within that of a particular pattern of human behaviour, that is sadly there, but which he does not want to make his own in his life. Of course, he does not understand his action as justifiable at all although it is now there whereas before, the possibility of that happening was not an issue. ${ }^{12}$

\footnotetext{
11 One must make the point that Peter's betrayal was not one of those cases where the circumstances were difficult to discern and where he could not easily make out what doing well really would amount to - so that he could have committed a mistake. Such an error is a different kind of 'going wrong' to akrasia. Indeed, the logical difference between this kind of situation and akrasia is readily observable: in the former case the agent would be readily open to correction at the time of acting.

12 It must be noted that Peter's remorse clearly shows that, despite the foolishness of his betrayal, he does not regard such aberrant actions as being committed by a different person. He could recognize himself in them. This is central and can easily be lost sight of. In effect, Peter's shift from that which he did not question and about which it made no sense to be doubtful, to that which constituted an aberrant move in his life took place
} 
When more normal circumstances prevailed again (which happened when Jesus looked at Peter), Peter looks in horror at what he has done. One must note, here, that, in the agent's reverting to his or her original character, there is an element of a fresh decision, aided by the release in the 'pressure' of the persuading situation. There is a decision to show remorse at one's actions. Of course the more truly the judgment one decided to overturn was part of the scaffolding of one's life, the more 'easy' is the decision to 'take up' again that which was not, in practice, doubted before. The terribleness of the deed committed is, however, another fact that is there as part of one's life and that may serve to convince the agent that, after all, in his previous practical world-picture he was not competent to judge. Indeed, some people are changed by an event in which they committed some deed which would have been unthinkable to them before. What is so tragic, in Peter's case, is that he passed from being someone for whom certain doubts were logically excluded because they informed his horizon of action, to being able to doubt and indeed deny his fidelity to Jesus. In acting incompatibly with what he could say is acting well, he did what, beforehand, he would have seen as being folly, and he did so intentionally. With horror, he can see that, in that respect, it was as if he were a different person.

within the 'nest of propositions' that formed his character. None of these ways of acting has a fixed position on its own account but only has such a role together with others in the world-picture that constitutes the agent's character. Some of them can change role within the element of the whole world-picture of the agent. However, it is inconceivable that all such 'logical' propositions change together: this is a logical requisite of continuing to speak of $a$ person at all. Similarly, it is also unimaginable that certain ways of acting are overturned abruptly in the life of a person; that would seem to knock from under the person's feet the 'ground' on which he or she can make any judgments at all. He or she would descend into chaos; all yardsticks of judging and acting would be swept away in his or her life. That would not be akrasia, but some kind of madness. 